\begin{tabular}{llll} 
Journal of Global Resources $\quad$ Volume 6 (01a) & Special Issue & June 2020 & Page 01-09 \\
\hline https://doi.org/10.46587/JGR.2020.v06si01.001 & ISSN: 2455-2445 (Online)
\end{tabular}

01

\title{
CORONAVIRUS: THE BEGINNING OF A NEW END?
}

\author{
Daniel Briggs \\ Faculty of Social Sciences and Communication, European University, Madrid, Spain \\ Email: daniel.briggs@universidadeuropea.es
}

\begin{abstract}
This short article uses data gathered from an online survey which 950 respondents completed from 58 different countries across the world. Respondents were asked about 1) their views of coronavirus, 2) the lockdown and social distancing, 3) their perceptions of media and government and 4) the future. The results of this paper draw on section 4 of the survey to discuss participants' views on what the coronavirus outbreak may mean for humanity in the future.
\end{abstract}

Key words: Coronavirus, Survey, Future, Change, Society.

\section{Introduction: The advent of Coronavirus}

In the West, people live in their own consumer bubble. They work only to spend and aspire to want what is in the shops and look for moments to indulge, and live our 'personal dreams' through consumption. This is how we 'enjoyed' our lives; this was how we spent our time up until a few months ago. Suddenly, the fast-paced almost invincible world which loved so dearly economic expansion and profit, ground almost immediately to a standstill. Having learnt nothing from 2008, the markets plummeted. All the news coverage related to Brexit started to dissipate. There was a new 'threat' supposedly coming to Europe. It would suddenly hit us they told us but we were too busy enjoying our liberal freedoms in commercial centres to worry about it. Then the virus hit us and whole countries locked down and sent their citizens home: we were at the mercy of the media unable to make sense of the 'real' and the 'fake', all the while absorbing contradictory information about how the virus and its effects. We became frustrated and anxious.

In a western culture dominated by advertising and mass media, we are relentlessly influenced to discard collective identities and exclusively pursue individuality through the symbols presented to us by the world of consumption. This inevitably leaves our 'individuality' anxious, incomplete, and, ultimately, a myth that reflects our growing distance from reality and our submersion in a commodified hyper-reality that has disrupted and displaced all collective forms and mutual interests. These comprehensive changes to everyday social experience play a significant role in the gradual transformation of human subjectivity into one that prefers the surrogate and hyperreal world of consumer goods over a confrontation with what is real and actually happening in society. What I am saying is that the role of consumerism in our lives prevents us from overcoming our primal fears about grave problems in the world and our own mortality. Therefore, this intensifies rather than transcends the emotional need for a coherent order of symbols, which can be met temporarily by Instagram and Netflix...but when that mask (literally) slips, reality's traumas multiply and bite hard. Will this fracture result in our total undoing? Could this be the jolt the social order needs to find a more collective moral pathway forward? Or is it a temporary glitch in this system of plastic entertainment? How can society change in the face of this new 'threat'? Can we pull together, can the social system change? A YouGov (2020) poll of 4,343 participants found that only 9 percent $(n=341)$ in their study said that they would like to see 'life go back to normal' meaning that a majority wanted a different structure to society. While to date, over 250,000 people have died as a result of the virus, the participants in the study clearly saw benefits to the coronavirus. Over half $(51$ percent, $n=2,214)$ appreciated the cleaner air while 27 percent 
$(1,162)$ said that they had noticed more wildlife in their local area. For over a third $(40$ percent, $n=1720$ ), the experience of lockdown because of the virus had a sense of community and 39 percent $(1,693)$ indicated that, as a consequence, they had been in contact more with family and friends (Wood et al., 2020). In environmental modelling that tracked four Chinese cities during the lockdown, Burke (2020) noted that the economic disruption potentially saved the lives of 77,000 who would have otherwise died of issues relating to air pollution. These are significant indicators that the public have noticed some difference and the sudden jolt to social life as we know it could be what is needed to make redundant the old model of society and mark the beginning of a new future.

\begin{abstract}
Aims and Methodology
The aim of the study was to study the social, psychological, and emotional impact of lockdown had on families and individuals during the coronavirus pandemic. The project made use of a 52 question semi-structured online survey which was split into five sections. The first section was about general questions about coronavirus and if people were worried, how long they had been in lockdown, how often they talked about it with others. The second section sought to ask about social distancing and self-isolating and whether the measures were appropriate, and what measures people took to avoid contracting the virus (wear a mask, gloves, etc.). The next section was on the specific experience of lockdown and how this had impacted on participants, those nearest them or indeed those farthest away from them; particular attention was given to feelings and habits which were undertaken more/the same/less as a consequence of the lockdown (sleeping, drinking, exercise, etc.). There was a section on perceptions of media and government asking participants to reflect on the credibility of the former and the performance of the latter. The penultimate section was a speculative set of questions about the future and, because of coronavirus, asking participants what it meant for the future and how did they think it now looked. Lastly, there was section recording typical demographic information. The survey took around 15 to 18 minutes to complete and was live during a period of one month from $30^{\text {th }}$ March to $8^{\text {th }}$ to May 2020 which covered lockdown for a large number of countries across the world. For the study to capture how people were feeling during the lockdown, data collection was only reserved for this period as leaving lockdown may have provoked other feelings. In total, 950 responses were made to the survey (see sample demography for further detail).
\end{abstract}

\title{
Sampling
}

Coronavirus currently affects everyone around the world for varying reasons so the sampling methodology should not discriminate as my principle aim was to see how this experience was felt during a finite period of time. To assure the appeal and reach of the survey it was translated into six languages which were English $(n=534)$, Spanish $(n=217)$, German $(n=69)$, French $(n=50)$ Italian $(n=49)$, and Arabic $(n=31)$. The choice of language was not necessarily made on any other basis than I had access to these translators at this period of time. The survey was advertised via Linked In on a daily basis in all six languages throughout the 'live period' of the survey. Additionally, it was also placed in Facebook forum discussion rooms based on Coronavirus (see Conroy et al. 2012). This project was unfunded so there was no budget for advertising for participation via social media (Bennetts et al. 2016; Gu et al., 2016), so I joined ten different public and private coronavirus discussion forums that covered Europe, America, South America, and Asia. General posts advertising the study with the relevant language links were undertaken twice a week while combined with posting general discussion questions (based on an element of the survey).

\section{Sample Demography}

Over the period in which the survey was open for completion, a total of 950 people completed it. Of those 950, two-thirds were women (66 percent, $n=623$ ) and one third were men (34 percent $n=324$ ) 
and three did not declare. This shouldn't be surprising as other studies on gender and Facebook users have found that women tend to use the social networking site more than men (Biernatowska et al. 2017; Alnajat et al. 2019). Participants from 58 different countries from around the world completed the survey and almost three quarters were aged between 20 and 49 (74 percent, $\mathrm{n}=699$ ) (see Table 1).

Table 01: Age Group of Sample

\begin{tabular}{|l|c|c|c|c|c|c|c|c|c|}
\hline Age group & $\mathbf{1 9}$ or under & $\mathbf{2 0 - 2 9}$ & $\mathbf{3 0 - 3 9}$ & $\mathbf{4 0 - 4 9}$ & $\mathbf{5 0 - 5 9}$ & $\mathbf{6 0 - 6 9}$ & $\mathbf{7 0 - 7 9}$ & $\mathbf{8 0}$ or Above & Total \\
\hline Number & 10 & 229 & 242 & 228 & 157 & 67 & 17 & 0 & 950 \\
\hline Percentage & 1 & 24 & 26 & 24 & 17 & 7 & 2 & 0 & 100 \\
\hline
\end{tabular}

Source: Field Survey

Just over half the sample was employed by companies (58 percent, $n=547$ ), nearly a fifth were self-employed (15 percent, $n=147)$ while 11 percent $(n=106)$ were students and 7 percent $(71)$ were unemployed. The remaining participants were retired.

\section{Results}

In this study which spanned the period of lockdowns in most countries, the sudden arrival of the 'virus' caught most unaware: it was something unexpected, a fiction that didn't appear real for many. When asked how participants felt when first learning about the virus in comparison to what they know about it now and how they feel about it, it was clear that the virus has made a substantial number of people at lease quite worried (47 percent, $n=424$ ) or very worried (22 percent, $\mathrm{n}=210$ ) (see Figure 1)

Figure 01: Feelings about the Coronavirus: 'When First Heard' Vs 'Now'

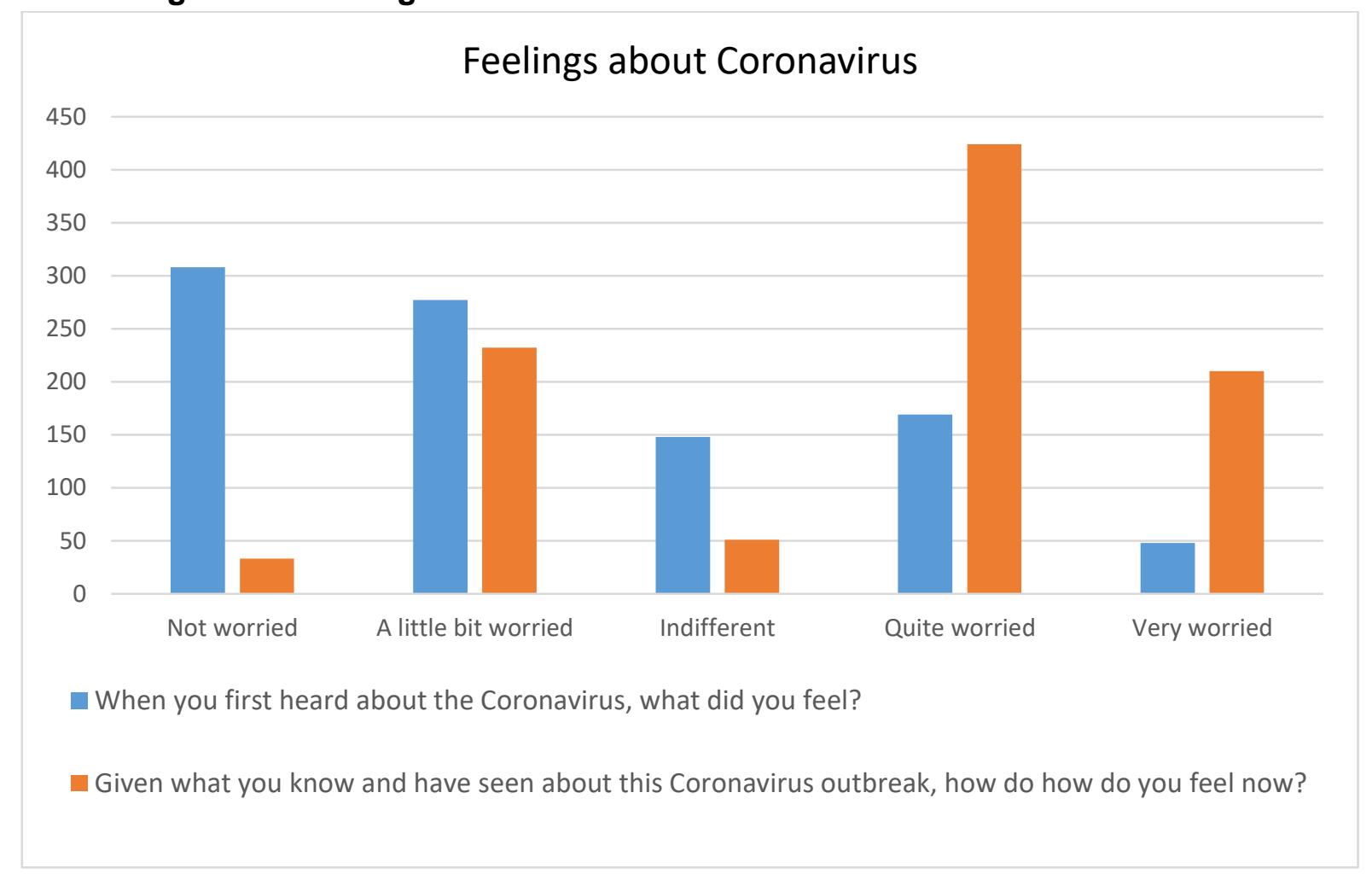

To put this change in collective feeling in some better context the number of 'quite worried' people more than tripled from $n=126$ to 424 and the number of 'very worried' people almost quadrupled from $n=61$ to 210 . (Stats taken from 'when first heard' vs 'now' respectively)

Early analyses of the data show that such an extreme shift was prompted by a number of different macro-political elements such as the 'risk' of the virus 
(contagiousness and death rates), governmental responses/management coupled with incessant media reporting and more social and subjective personal factors such as socio-economic and/or labour circumstances, personal health status, and individual psychological state. While these particular areas have not been considered for this article due to space restrictions, these are important components to prompting a change in perception that many felt very close to them, like this woman from Sweden:

"I think we've become way too disconnected from ourselves, spending our lives in a constant state of stress and rarely making time for just taking things slow and reflecting over our lives and ourselves. Because of lockdown a lot of people are now pretty much forced to slow down and confront themselves, which I suppose is a good thing. For some, it may be a wakeup call, as they may realize they've been spending their time focusing on the wrong things. In that the way the coronavirus crisis can be the catalyst someone needed to turn their life around." (Female, 30-39, Sweden)

The lockdown experience took people out of their everyday circumstances of work, family, routine and imposed on them a new set of norms and conditions which, in turn, started to reshape how they organized their lives. In the UK for example, a slow governmental response combined with conflicting stances on when a lockdown should take place and under what conditions, and sudden vulnerability of millions of people, many communities showed solidarity and started working together for each other:

"Communities are coming together more, people are volunteering more to help one another and hopefully that will continue, people are learning to appreciate the simple things in life, people are getting their priorities straight, everyone is having to slow down and become more aware of their own mortality and that of people they love." (Female, UK, 40-49)

In fact, when the UK government realized they couldn't do it alone nor had the resources to cope with putting lockdown measures in place while assisting the vulnerable, they endorsed public support by asking people to 'clap for them' and put out a call for volunteers. More than half a million people put themselves forward to assist in supporting the health services - which had been dilapidated in the face of years of cuts and austerity politics (Murphy, 2020). Still this had other people feeling doubtful about, even in the face of such 'solidarity', that this could translate to 'change':

"I am fascinated with the "we are all in this together" but are we really? Are we really still divided by economic/class? Hollywood, athletes, media personalities, upper class have the means to get tested but what about how this is compared to the poor?" (Female, USA, 6069)

"There is the potential to rethink our current system which is just waiting for the next crisis to come (e.g. climate collapse) or the kind of work we value, but I'm pessimistic about that actually going to lead to change." (Male, Austria, 20-29)

"I think things will either sooner or later will go back to how they were because this is how we are. I very much hope it is not going to be how things become, but I do think we will end up in the same mess from where we started. Maybe the scientific community will have better cooperation among themselves, maybe more people will continue to cook for themselves, but in general, most people will continue to get back to the way things were. I hope not, but I think so." (Male, Hungary, 30-39)

For some participants the advent of the coronavirus exposed the system, its inequality and, in some cases, a feeling of scepticism among a few highlighted in this quotes above. When asked 
whether coronavirus exposed the fragility of society or its potential to demonstrate solidarity, there was a tendency for people to indicate the latter (Figure 2).

Figure 02: Views on Whether the Advent of Coronavirus Exposes the Fragility of Society Vs How it Can Show Solidarity

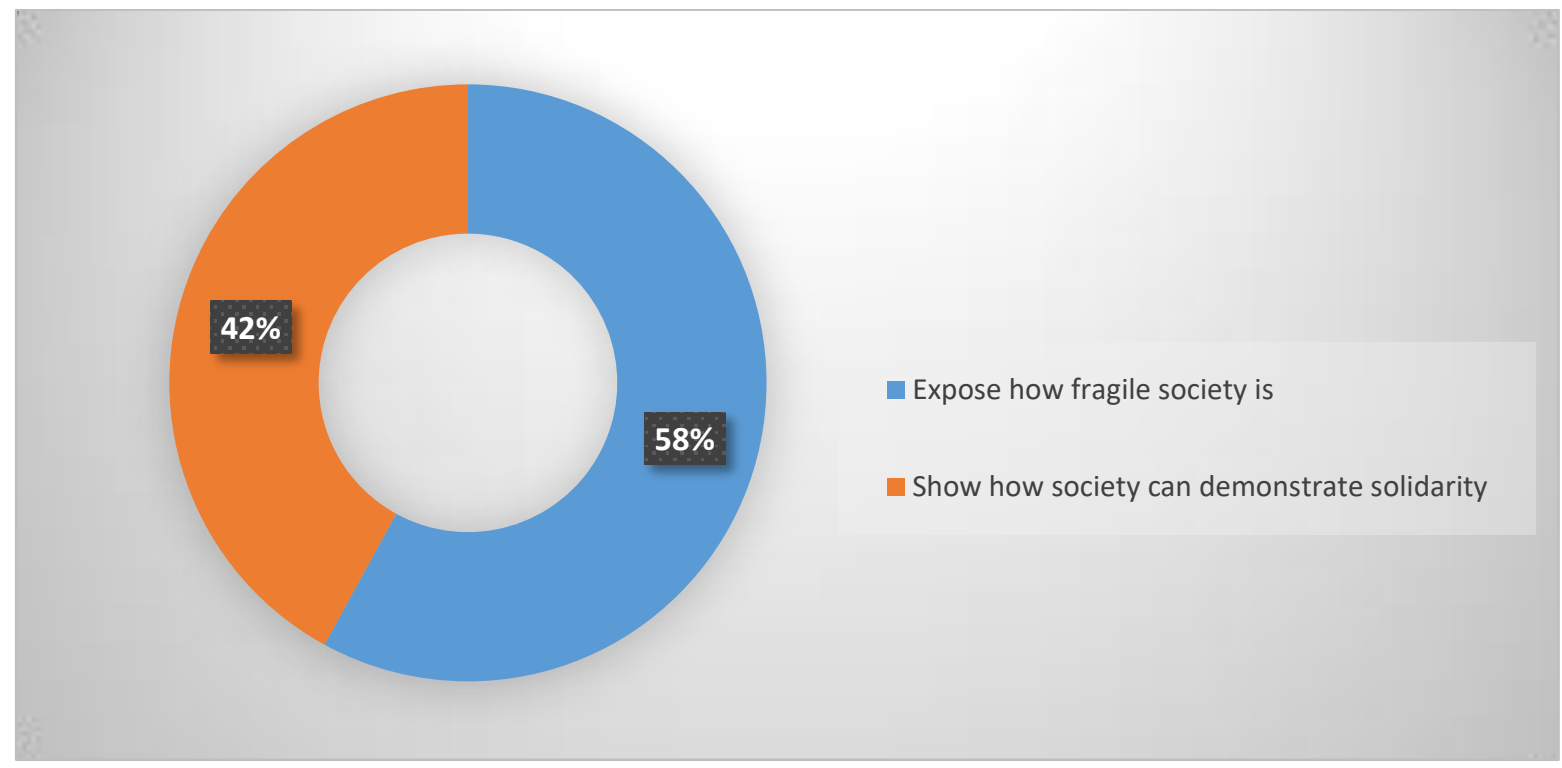

This dichotomy between 'solidarity' and 'fragility' was recognized by some participants; the former tending to be seen as a temporary feature while the latter to exacerbate poverty and social suffering as these three quotes from participants from Turkey, Brazil and Portugal indicate:

"Everything has a benefit ... as the virus now shows how important it is to unite all groups of society and all state institutions." (Male, Turkey, 20-29).

"Maybe it can expose the contradictions of the capitalism, make people more aware of how the rich are just trying to screw us up. Then, maybe we could start some new solidarity networks. I just joined one to help!" (Brazil, Male, 40-49)

"Well, I think that by now ... those benefits exist only in a 'potential form' - we would need some strong reflection work during and after the crisis to actually create benefits out of this. Of course, the pollution dropped and some solidarity has been shown, but for how long will they last after this is over? On the other hand, I fear that social unbalance will be even stronger, and the poorer will be left with even less resources. I think this could be a great opportunity for one to reflect on the way we are living, but we are really billions of people around the world, and it's kind of impossible to reflect globally, so I'm very sceptical about this. Not such a bad case scenario, but I think we will continue as before." (Male, Portugal, 40-49).

So the virus, its risk and a sudden rupture in the status quo in everyday life prompted many people to rethink their current situations and reflect on the state of the world in the face of a virus which they perceived to be here for medium-to-long term (see Figure 3). Nearly three-quarters of the sample (71 percent, $n=672$ ) expected the virus to return in some form (Figure 3 ). The uncertainty around these renewed 'waves' of infection as well as a reliable and widely-available vaccine coupled with the accumulating debt as governments throw money at science and prop up millions of people in their respective economies creates collective insecurity and major doubt about the future. This was certainly evident in these three quotes from people from Chile, UK and Morocco: 
"I don't know, I think that in a few months we will be able to see benefits or destruction because everything depends on what happens in the impact of the world economy." (Female, Chile, 30-39)

"I have concerns about those living in cramped, challenging and abusive conditions and the impact on global economy and forgotten issues - migration, war, poverty, other diseases and the impact on mental health for those who are alone etc." (Female, UK, 40-45)

"There are no benefits at all. Rather, on the contrary, society is tired and people feel anxious and constantly afraid of the unknown, and there is no longer hope for humans to do anything." (Male, Morocco, 50-59)

\section{Figure 03: Perceptions of Short-to-Medium-to-Long Term Life of the Virus}

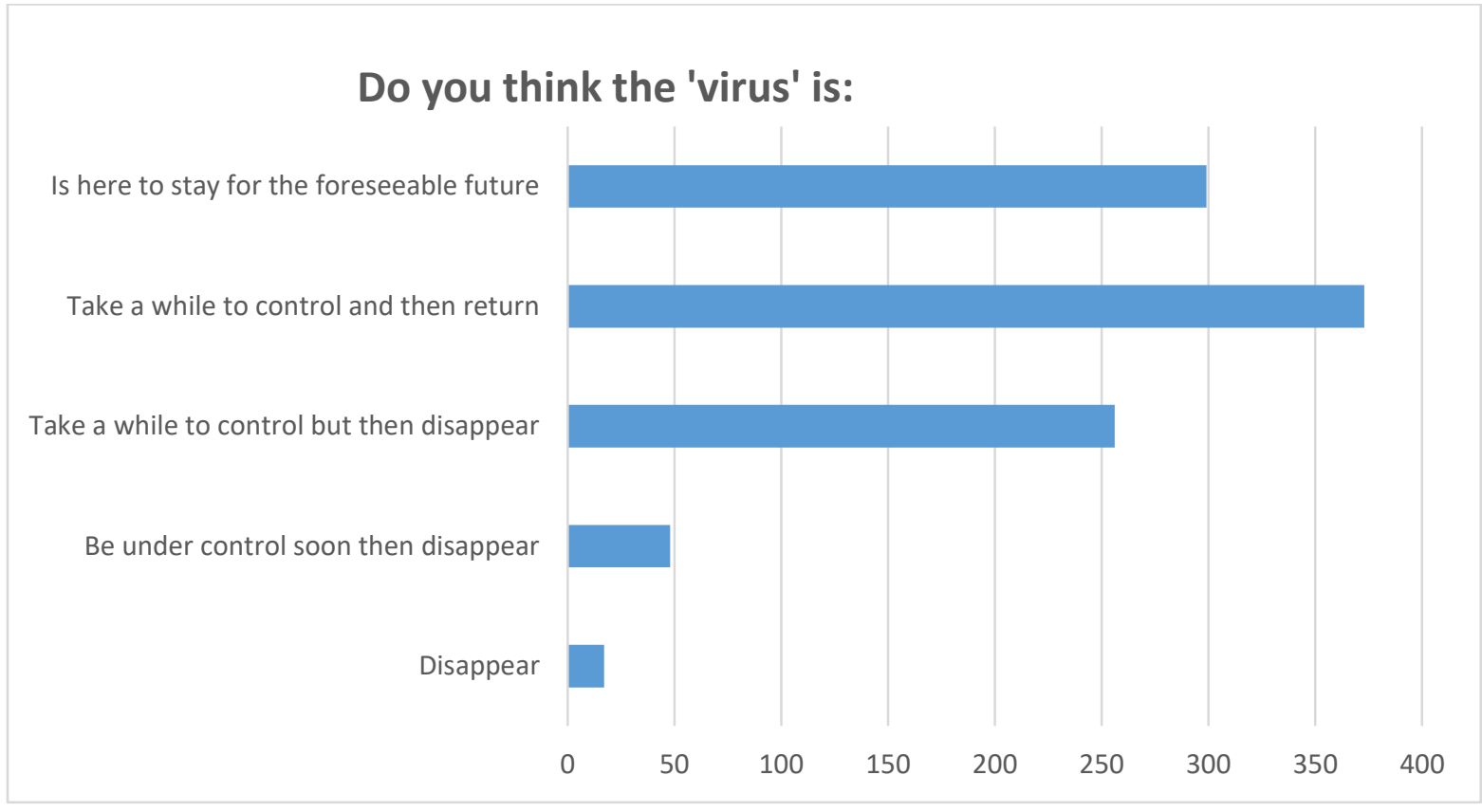

What the future holds, however, we cannot say or know. What seems quite clear though is that that the future is now different (see Figure 4).

Figure 04: Coronavirus and the Future

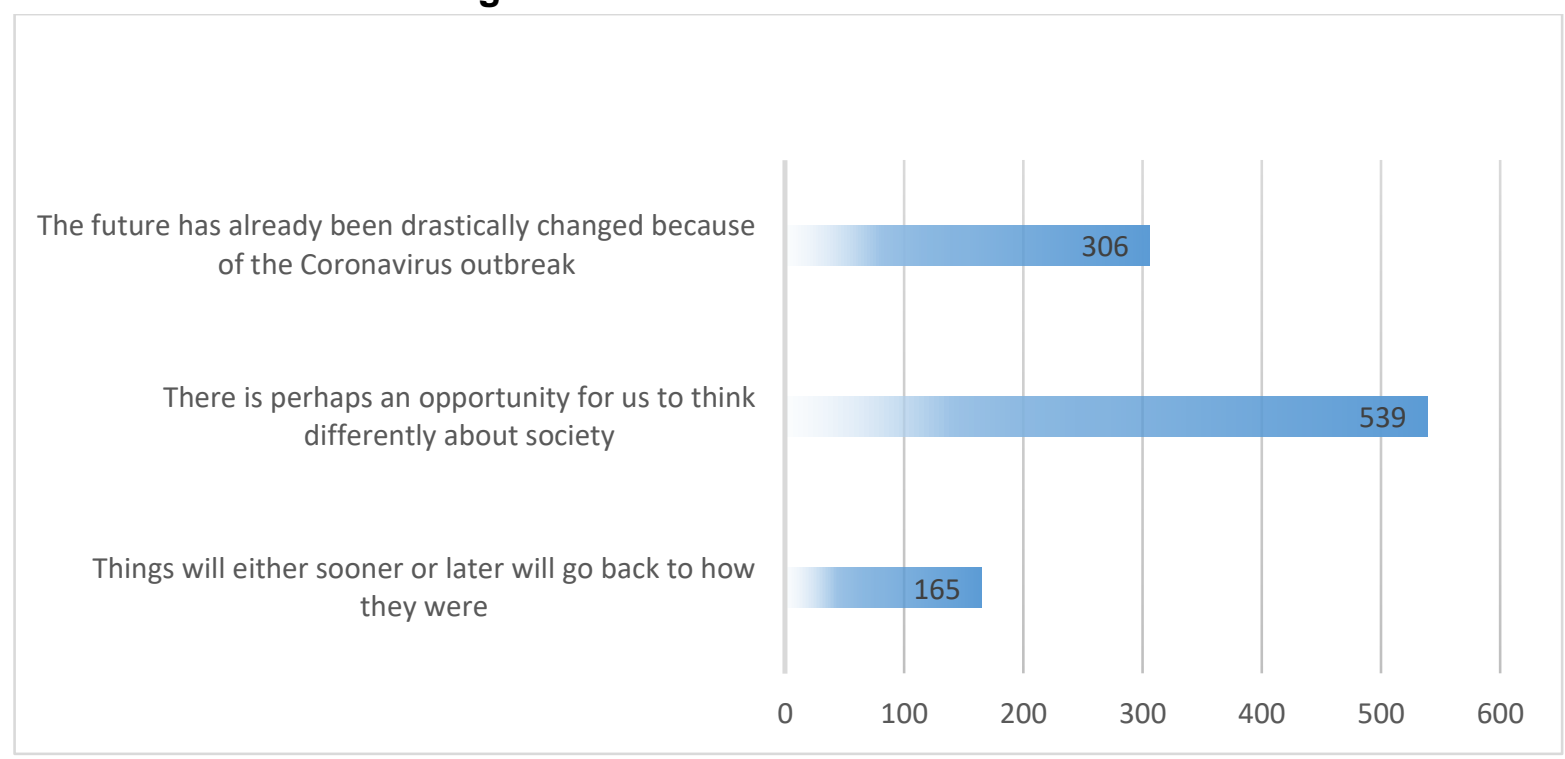

While there is general agreement at least that this is an opportunity to think about potential change, there was also ambiguity. This was reflected in how participants felt about their 
professional futures, or that of their families, in the context of work/education (see Figure 5) for over one-third of the sample felt that 'coronavirus had placed many doubts in their mind about the future' as this woman from the US wrote:

"My biggest stressor right now is the economy. There are already more people unemployed and more to come. I'm worried about my husband losing his career even as things start to bounce back. He's a pilot and 9/11 saw a 12-year furlough for many. That's terrifying. I'm also worried about the mental health of people; I know our local hospital has already seen a spike in demand. Being alone and stressed isn't a good combination for anyone, let alone someone with a history of depression and anxiety." (Female, USA, 30-39)

\section{Figure 05: How Do You Feel About Your Professional Future or that of Your Families?}

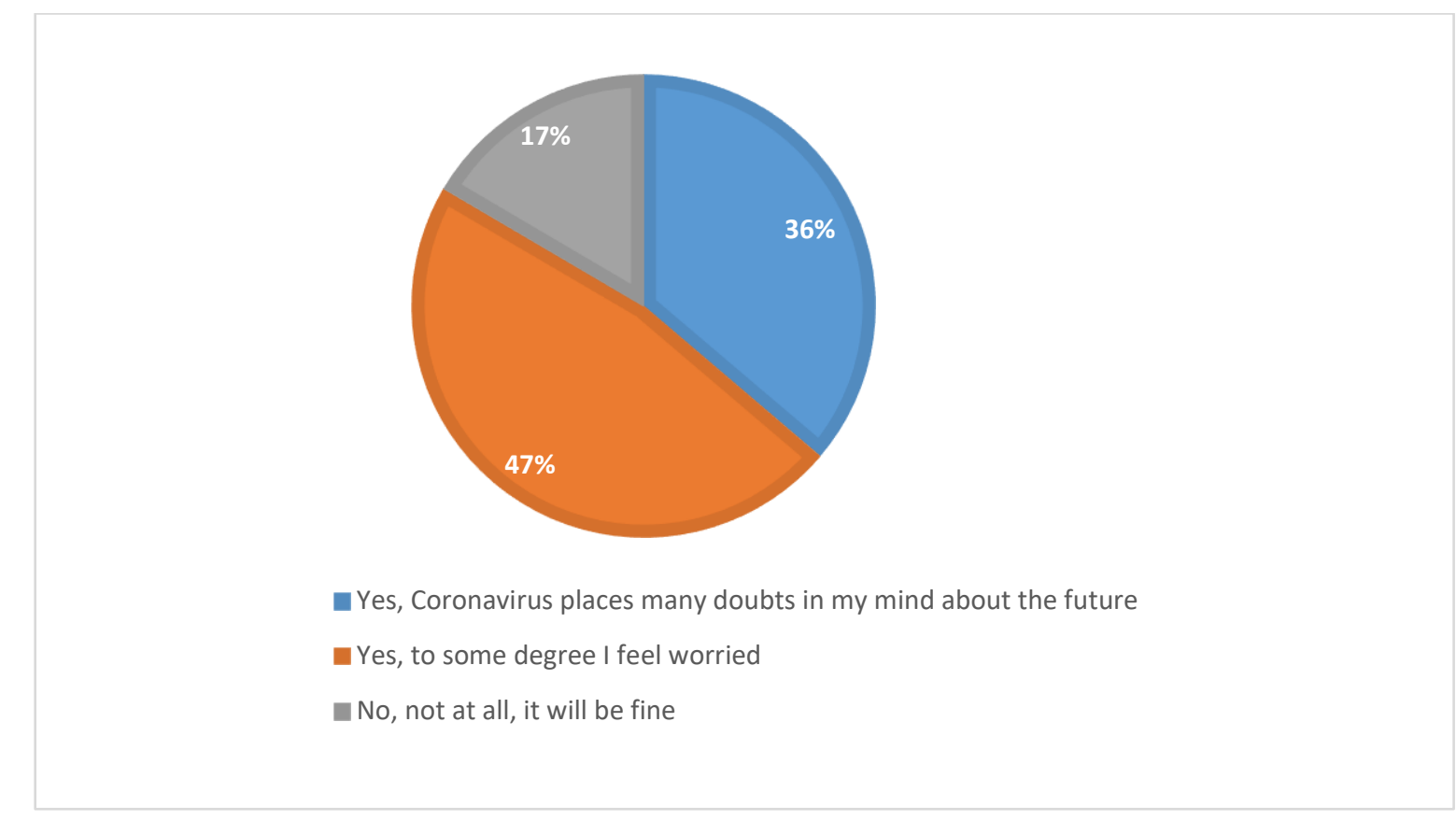

Perhaps we now feel a little bit more professionally redundant as nurses, supermarket cashiers, waste workers and the like continued working during the lockdown despite the potential high risk of infection. In the end, it was these people in these forgotten public service industries which enabled the world to continue to function at its most basic level:

"Rethinking our way of living, consuming, moving around. At the political level, understand that we have gone too far in our capitalist Western societies where only money counts. Today, which jobs are still essential on which people still move around? Education and health. These are underpaid and very little valued jobs, even though they are the most important ones." (Male, France, 30-39)

In a situation where mass debt could prompt governments to be more scrupulous about spending may dent our newfound 'social consciousness for supporting everyone in a global society as Figure 6 indicates. When asked 'in a situation which would see most people contract the virus, should we either spend money on either a) protecting the vulnerable at any cost or b) ensuring the safety of the majority' public opinion was split: 


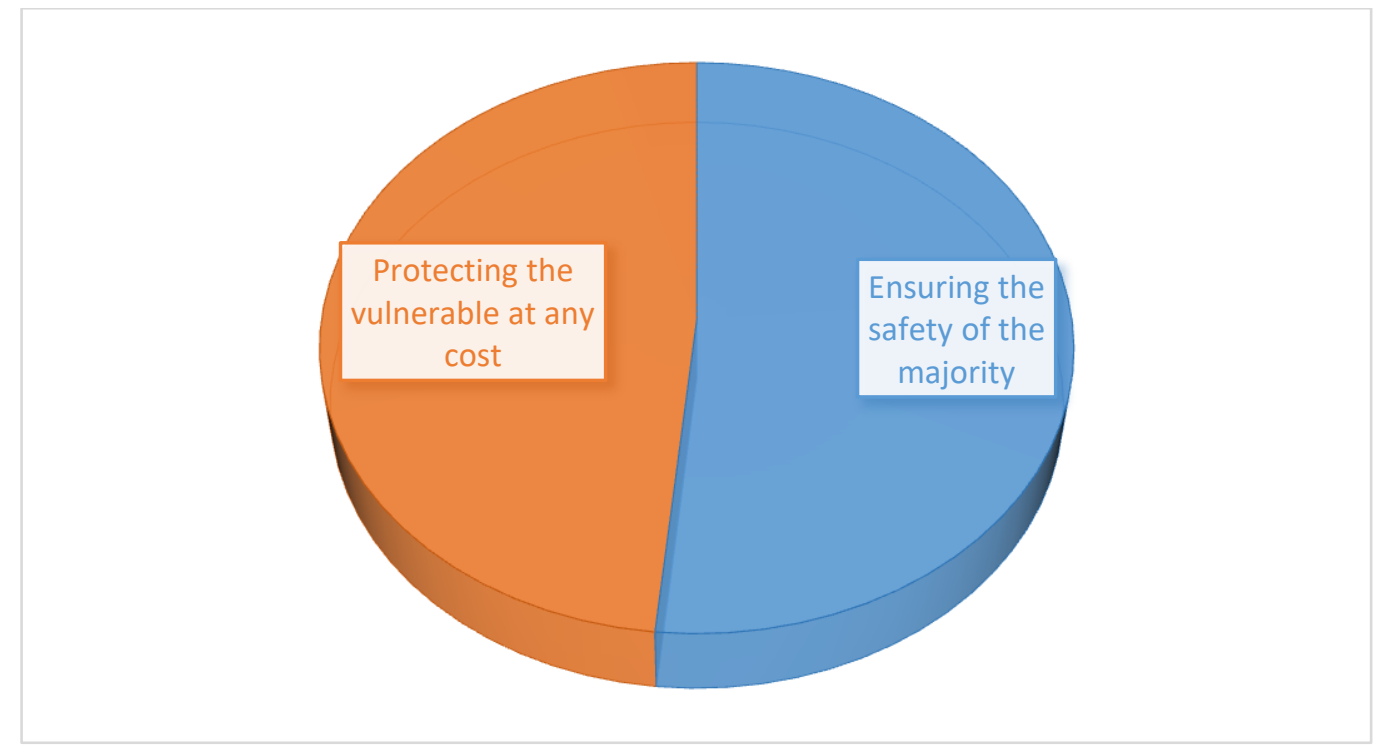

For now, all we can do is hope for the elusive 'curve' to flatten, wash our hands and follow the news for a vaccine.

\section{Conclusion}

This paper has attempted to measure how the experience of lockdown for 950 people from 58 different countries around the world has impacted on perceptions of the future. I have used a quantitative methodology to gather this information via an online survey of which used a sampling methodology via Facebook and Linked-In. There is no doubt that the survey did not reach the poorest of the world's populations for this as this participant recognized from Honduras:

"There is a need to compare our middle-class lockdown and its impacts with those who are in real poverty, without access to space, internet, food, water, remote work and healthcare. This virus is shown in some social media as a lovely street party creator but also is creating huge inequality and risk for those who are not so fortunate and it is to these people we should focus our efforts on helping." (Male, Honduras, 40-49)

Undoubtedly, the majority of my participants wrote their responses from places of privilege by comparison in that most have places to live. This said I was interested in how the experience of lockdown was felt personally and emotionally for these people, and how combined with media influence and the way their governments and health systems were dealing with the virus, impacted their perceptions of the future.

The results of the survey seem to reveal, on the one hand, that the arrival of coronavirus, its impact on their society and the subsequent lockdown provokes some self-reflection and allowed many people to re-evaluate to some degree elements of their professional and personal lives and about the way the world works. Of note, was the connection some had found with other people and solidarity networks while others had quite utopian ideas about how the world could change, about how human rights could be improved for people and how a greater social justice might prevail as a consequence of all this? On the other hand, there was a sense of scepticism about how the global the system could change, perhaps reflective by a feeling of impotence: that the scale of change was in fact too broad and it, because of issues like climate change, it was all happening a bit too late as this man from the UK wrote: 
"I do hope I'm wrong and that we change but clapping and volunteering is not new. These are cheap and 'easy'. Radical change is hard. Like climate change. If we want to change we have to make the tough decisions." (Male, UK, 30-39)

The quote from this man which refers to the UK's volunteer scheme and solidarity efforts to 'clap' NHS staff pierces the ideological neoliberal mantras and gets to the core of the issue: instigating real social change. What seems certain is that some form of restructuring will be required. The big question relates to a) will it either drastically reform the world order; b) will things return to the pre-coronavirus normal and neoliberalism will continue with its 'business as usual'; or c) will the current status quo be exacerbated in the wake of our economic 'recovery' and we see neoliberalism become more powerful and unmerciful. Should we continue to confide in the existing frameworks of social policy, international law and commercial ventures, we should expect things to deteriorate because of the way in which the coronavirus is unfolding highlights the deficits of the current system and its operations. New ideas need to be realized to sew up society's mass gashes and open bleeding so the question will be how quickly and efficiently the world's political surgeons can operate what tools they use and if they discover the right treatment.

\section{References}

1. Alnajat, R., Hmaidi, M., Samha, S., Kilani, M., Hasswan, A. (2019). Gender variations in social media use and academic performance among the students of the University of Sharjah. Journal of Taibah University Medical Sciences, 14(4): 390-394.

2. Biernatowska, A., Balcerowska, J., and Bereznowski, P. (2017). Gender differences in using Facebook—preliminary analysis' in J. Nyćkowiak \& J. Leśny (Eds.), Badaniai Rozwój Młodych Naukowców w Polsce - Społeczeństwo: psychologiaisocjologia. pp. 13-18. Poznań, Poland: MłodziNaukowcy.

3. Burke, M. (2020). Global Food, Environment and Economic Dynamics cited online at http://www.g-feed.com/2020/03/covid-19-reduces-economic-activity.html on 11th May 2020.

4. Conroy, M., Feezell, J., and Guerrero, M. (2012). Facebook and political engagement: A study of online political group membership and offline political engagement. Computers in Human Behavior, 28: 1535-1546.

5. Gu, L., Skierkowskia, P., Florin, P., Friend, K., and Yea, Y. (2016). Facebook, Twitter, \& Qr codes: An exploratory trial examining the feasibility of social media mechanisms for sample recruitment. Computers in Human Behaviour, 60(2): 86-96.

6. Wood, V. (2020). Britons enjoying cleaner air, better food and stronger social bonds say they don't want to return to normal' in The Independent $17^{\text {th }}$ April 2020 , cited online at https://www.independent.co.uk/news/uk/home-news/coronavirus-uk-lockdown-end-pollenvironment-food-health-fitness-social-community-a9469736.html on 11th May 2020. 